preventive and curative health responses needs to be reconsidered. Development of immediate health strategies, policies, and interventions are the most important of the present day and this development has to move ahead from promises to practices. The gap between healthcare professionals and the patients must be narrowed if optimal results are to be achieved. This may result in the change of perception and the development of trust in medication that will lead to ideal pharmaceutical care.

\section{Fahad Saleem,}

PhD candidate, Discipline of Social and Administrative Pharmacy, School of

Pharmaceutical Sciences,

Universiti Sains Malaysia.

E-mail: fahaduob@gmail.com

\section{Mohamed Azmi Ahmad Hassali,} Senior Lecturer/HOD, Discipline of Social and Administrative Pharmacy, School of Pharmaceutical Sciences,

Universiti Sains Malaysia.

\section{Asrul Akmal Shafie,}

Senior Lecturer, Discipline of Social and Administrative Pharmacy, School of

Pharmaceutical Sciences,

Universiti Sains Malaysia.

\section{REFERENCES}

1. Benson J, Britten N. Patients' decisions about whether or not to take antihypertensive drugs: qualitative study. BMJ 2002; 325(7369): 873-876.

2. Britten N. Patients' ideas about medicines: a qualitative study in a general practice population. $\mathrm{Br} J \mathrm{Gen}$ Pract 1994; 44(387): 465-468.

3. Bichmann W. Primary health care and traditional medicine - considering the background of changing health care concepts in Africa. Soc Sci Med Med Anthropol 1979; 13B(3): 175-182.

4. Edwards SD. Traditional and modern medicine in South Africa: a research study. Soc Sci Med 1986; 22(11): 1273-1276.

DOI: 10.3399/bjgp10X515467

\section{Revalidation}

In the double speak of Big Brother, Mike Pringle and Steve Field hold the banner of revalidation like Custer at the last stand.

David Edgcumbe has clarified what most hardworking conscientious GPs have known for years. When it comes to revalidation there is little support from College Members and fewer from outside the College. ${ }^{1}$ I raised this at Council 2 years ago, but College Council packed with GPs who do not feel the heat of wallto-wall consultations have no realisation that the Emperor has no clothes.

Quality general practice has no room for performing like a circus clown every 5 years. Despite all the platitudes that it is about professional development, it is about measuring what we cannot measure and removing GPs who do not tick the boxes.

As a UK GP abroad, I see the barriers being erected to prevent UK GPs returning from New Zealand or Australia which will cement the loss of UK doctors. To require GPs, who in my experience are more competent than those in the UK, to jump these hurdles will ensure that they stay abroad.

Let us vote and see if the Emperor really does have clothes.

\section{David Stephens,}

Waihi, New Zealand.

E-mail: david.stephens2@nhs.net

\section{REFERENCE}

1. Edgcumbe D. Let's take a vote on revalidation. $\mathrm{Br} \mathrm{J}$ Gen Pract 2010; 60(576): 537.

DOI: 10.3399/bjgp10X515476

\section{New competencies ignored: general practice is in danger in Italy}

As The European Academy of Teachers in General Practice and Family Medicine specifies, GP trainees have to be trained in the specific competencies this profession requires. These competencies have been defined on the grounds of the traditional expectations of GPs but are in need of evaluation, revision, and directed development for the immediate future of general practice.

According to Nigel de KareSilver, ${ }^{1}$ there are a range of new competencies that require the advocacy of general practice within the medical profession: leadership, representation in society, academic and journalistic writing, teaching of students, trainees, and doctors from other specialties, advising professional bodies, both governmental and scientific, and research.

Currently, in Italy very little is taken in to account of this new skill set when recruiting or training graduates, nor at the undergraduate level where we are only at the first step in creating courses with a core general practice curriculum in a few centres in Milan and Rome. Some big and underfunded changes are on the horizon in the reorganisation of delivery of health care. These would strongly impact on the social role of the GP. ${ }^{2}$

Established GPs are extremely frustrated at being pulled and pushed by politicians and technologists with big and unrealistic decisions in the form of diktat.

In Italy there is a serious danger that GPs, so nationally divided with no effective lobby, would be 'changed' into a new breed of clinician, little more than bureaucratic officers or clerks, becoming a new group in which the holistic relational core competencies will be lost before new ones are learned and applied. ${ }^{3}$ In Italy there is no flexible scheme to provide protected time for teaching, research, or leadership. As a consequence, social needs will receive little consideration and GPs will perform only low-level duties, be subservient to local health politicians, and eventually progressively escape from family medicine, resulting in falling GP numbers from the loss of established doctors through retirement that will not be replaced due to the falling number of GP trainees.

\section{Francesco Carelli,}

Professor of Family Medicine, University of Milan. E-mail: carfra@tin.it

\section{REFERENCES}

1. De Kare-Silver N. Training for change. Br J Gen Pract 2010; 60(576): 542-543.

2. IMF External Relations Department. International Monetary Fund. IMF Executive Board Concludes 2009 Article IV Consultaion with the United Kingdom. http://www.imf.org/external/np/sec/pn/2009/pn0984.ht 
m (accessed 9 Aug 2010).

3. Carelli F. Family medicine crisis? Synapse Magazine $2009 ; 12$.

DOI: 10.3399/bjgp10X515485

\section{Loch Eport}

A few comments on Alec Logan's paragraph and photograph. ${ }^{1}$ His latitude and longitude, I'm sure, are immaculate and the exquisite pink flowers are Thrift or Sea Pink (Armeria maritima), that grow in great profusion on the Hebridean coasts in summer. The loch pictured however, is Lochmaddy, not Locheport and the hill is Eaval, not Heaval, that every BJGP reader must know is on the island of Barra! I agree with nomenclature, that almost every hill in the Outer Hebrides has the Norse suffix -val (fjall or Fell). I was born and lived there, until I left for the first time aged 15 to further my schooling. I appreciate his kind remarks about my native isle and wish him many happy returns.

\section{Alastair Morrison, Sidinish, Ferntower Road, Crieff, PH7 3DH. E-mail: gpmorrison@secaurazone.net}

\section{REFERENCE}

1. Logan A. Loch Eport. Br J Gen Pract 2010; 60(576): 547.

DOI: 10.3399/bjgp10X515502

\section{Smoking cessation}

I read with interest the leader by Patrick White. ${ }^{1}$ I share his enthusiasm for smoking cessation and pulmonary rehabilitation. I do not, however, share his enthusiasm for inhaler therapy beyond short-term betaagonists. The evidence for long-term reductions in exacerbations and admissions is there but it is hardly striking. I do not think that we should extrapolate reductions in mortality until that evidence is there. The fact that it is not already, suggests that any reductions, sadly, won't be too great.
My concerns are that, once labelled the path of prescribing moves almost automatically to short-acting betaagonists, long-acting beta-agonists, and inhaled steroids in all patients, even in those with mild disease and even in those with no objective or subjective hard evidence of improvement. How can we make treatment more objectively useful?

I do not want to be a therapeutic nihilist but equally this disease needs cost effective, evidence-based treatments that are re-assessed and stopped if they don't work. A huge sum is being spent promoting the benefits of multiple treatments, but rarely do these promotions emphasise, for instance, the increased pneumonias in people with chronic obstructive pulmonary disease who are being treated with inhaled steroids.

\section{John Sharvill,}

GP, Balmoral Surgery, Canada Road, Deal, Kent, CT14 7EQ.

E-mail: john.sharvill@nhs.net

\section{REFERENCE}

1. White P. COPD in primary care: a time of opportunity. Br J Gen Pract 2010; 60(576): 477-478.

DOI: 10.3399/bjgp10X515494

\section{MMR and egg allergy: to vaccinate or not to vaccinate?}

We do receive a number of referrals every year (10-15) from GPs for MMR to be administered in a hospital setting. The live measles and mumps vaccine is grown on cultured chick embryo fibroblasts and there is a concern that there could be some amount of egg protein in the vaccine. The controversy surrounding MMR and egg allergy has been long standing even though the hen's egg protein in the vaccine is highly processed and the concentrations are very low to trigger any allergic reaction. ${ }^{1}$ There has been a vast amount of evidence ${ }^{2,3}$ published already about the safety of MMR in children with egg allergy. In spite of various recommendations and guidelines, children are still being referred for MMR to be administered in a hospital setting.

The guidance in the UK surrounding MMR and egg allergy has changed over the years. The recommendations for MMR vaccine in egg allergic children were published in 2000. ${ }^{1}$ It stated that children with mild egg allergy can be safely vaccinated in primary care and recommended that children with previous significant allergic reactions should be vaccinated in hospital. Most of our practice is still based on these recommendations.

The latest British Society of Allergy and Clinical Immunology (BSACl) guidance recommends that all children with egg allergy should be immunised in primary care. 'Children who have had documented anaphylaxis to the vaccine itself should be assessed by an allergist'. ${ }^{4}$

Our approach has always been to write back to GPs or to speak to them directly about the safety of MMR in egg allergy. We, however, do not know if any of these children did ever go on to have the vaccine in primary care.

We agree with the recommendation by Ainsworth et a ${ }^{5}$ of attaching a copy of $\mathrm{BSACl}$ guidelines when we write back to our GPs. Although the guidelines have been published, there is still a possibility that many of our colleagues in primary care are not aware of them. We believe that inclusion of these recommendations in all the immunisation leaflets and related websites would lead to increased awareness and reduce the confusion surrounding this controversy. We hope that the green book would include the same advice in its next edition.

Srinivas Bandi, Consultant Paediatrician, University Hospital Coventry, Clifford Bridge Road, Coventry, CV2 2DX. E-mail: seenu_dr@hotmail.com

Colin MacDougall,

Consultant Paediatrician, University Hospital Coventry, Clifford Bridge Road, Coventry. 